\title{
Noble Gas Record of Japanese Chondrites
}

\author{
Nobuo Takaoka \\ Department of Earth Sciences, Faculty of Science, Yamagata University \\ Masako Shima and FumitakaWakabayashi \\ National Science Museum, Tokoy \\ Z. Naturforsch. 44a, 935-944 (1989); received August 5, 1989 \\ Dedicated to Professor Heinrich Wänke on the occasion of his 60th birthday
}

Concentrations and isotopic ratios of noble gases are reported for nineteen Japanese chondrites. Among those, Nio (H3-4) is a solar-gas-rich meteorite.

$\mathrm{U} / \mathrm{Th}-\mathrm{He}$ ages are younger than $\mathrm{K}-\mathrm{Ar}$ ages for all meteorites studied. Six of the nine L-chondrites give significantly young $\mathrm{K}-\mathrm{Ar}$ ages, suggesting gas loss by impact shock heating. The remaining three L-chondrites and seven of the ten $\mathrm{H}$-chondrites have $\mathrm{K}$-Ar ages older than $4 \mathrm{Ga}$. The L-chondrite Nogata and the H-chondrites Numakai, Ogi and Higashi-Koen have concordant ages.

Cosmic-ray exposure ages for six of the $\mathrm{H}$-chondrites show clustering around the 6-Myr peak in the distribution of exposure ages, while those for the L-chondrites, ranging from 8.2 to $64 \mathrm{Myr}$, do not show clustering.

Fukutomi (L 4) contains trapped ${ }^{36} \mathrm{Ar}$ in excess, 3.5 times enriched compared to the highest value so far reported for type-4 ordinary chondrites except solar-gas-rich chondrites. The ${ }^{36} \mathrm{Ar} /{ }^{132} \mathrm{Xe}$ and ${ }^{84} \mathrm{Kr} /{ }^{132} \mathrm{Xe}$ ratios fit along a mixing line between a planetary and a sub-solar (or argon-rich) component found in separates of E-chondrites [43]. The Xe isotopic composition is identical with that in Abee and Kenna. The isotopic signatures suggest that this meteorite may contain mineral fragments bearing the noble gas component found in E-chondrites or ureilites.

Fukutomi also contains ${ }^{80} \mathrm{Kr},{ }^{82} \mathrm{Kr}$ and ${ }^{128} \mathrm{Xe}$ produced by epithermal neutron captures on ${ }^{79} \mathrm{Kr}$, ${ }^{81} \mathrm{Kr}$ and ${ }^{127} \mathrm{I}$, respectively. From the neutron-produced $\mathrm{Kr}$, the preatmospheric minimum radius is estimated to be $20 \mathrm{~cm}$ with an assumption of a spherical meteoroid.

\section{Introduction}

Concentrations and isotopic ratios of noble gases in stony meteorites imply much information about the history of the solar system. Such information is obtained through trapped primordial gases and products of nuclear decays and nuclear reactions between cosmic-rays and target nuclides in the meteorites.

Since Japanese chondrites studied in this work are observed falls except Shibayama, their terrestrial histories are known. Therefore it could be easy to resolve any problems that are introduced by terrestrial effects such as contamination and weathering.

We will present the noble gas records of nine L-group and ten H-group chondrites. Chemical, mineralogical and petrographical studies of these chondrites [1-18] and determinations of cosmic-rayproduced ${ }^{26} \mathrm{Al}$ and ${ }^{53} \mathrm{Mn}[19,20]$ have been reported elsewhere.

Reprint requests to Dr. Masako Shima, National Science Museum, 7-20, Ueno-Park, Taito-ku, Tokyo 110, Japan.

\section{Experimental Procedures}

\subsection{Sample Description}

The samples studied in this work are listed in Table 1. The chemical, petrographical and mineralogical features are given in the literature cited. They are ordinary chondrites of various petrologic types. The date of fall ranges from 861 A.D. to 1986 A.D. The recovered masses are rather small, less than $1 \mathrm{~kg}$ for two thirds of the meteorites. K concentrations used for $\mathrm{K}$-Ar age calculations, determined chemically or by a non-destructive $\gamma$-ray method, are also given.

\subsection{Noble Gas Analysis}

Bulk meteorites, weighing between 0.03 and $0.3 \mathrm{~g}$, were wrapped in $\mathrm{Al}$-foil (approximately $15 \mathrm{mg}$ ) and degassed in vacuum at about $100^{\circ} \mathrm{C}$ for a night in side arms of a sample holder. After blank runs, the samples were dropped into a thorougly degassed molybdenum crucible and heated at $1750^{\circ} \mathrm{C}$ for 30 minutes. For Fukutomi (L4), which showed significant enrichments

0932-0784 / $89 / 1000-0935 \$ 01.30 / 0$. - Please order a reprint rather than making your own copy. 
Table 1. Chondrites studied in this work.

\begin{tabular}{|c|c|c|c|c|c|}
\hline Chondrite & Class & Date of fall & $\begin{array}{l}\text { Recovered } \\
\text { weight }(\mathrm{kg})\end{array}$ & $\begin{array}{l}K \\
(\mathrm{ppm})\end{array}$ & Ref. \\
\hline Fukutomi & L4 & $19 / 03 / 1882$ & 16.77 & 980 & {$[4,12]$} \\
\hline Tane & L 5 & $25 / 01 / 1918$ & 0.906 & 914 & {$[4,17,19]$} \\
\hline Nogata & L 6 & $19 / 05 / 0861$ & 0.472 & 950 & \\
\hline $\begin{array}{l}\text { Satsuma } \\
\text { (Kvushu) }\end{array}$ & L6 & $26 / 10 / 1886$ & $>46.5$ & 971 & {$[1,19]$} \\
\hline Nagai & L6 & $30 / 05 / 1922$ & 1.81 & 1080 & [9] \\
\hline Duwun & L6 & $23 / 11 / 1958$ & 2.117 & 770 & {$[13]$} \\
\hline $\begin{array}{l}\text { Shiba- } \\
\text { vama }\end{array}$ & L6 & found 1969 & 0.235 & 730 & [11] \\
\hline Aomori & L6 & $30 / 06 / 1984$ & 0.32 & 890 & [17] \\
\hline Kokubunji & L6 & $29 / 07 / 1986$ & $\sim 11$ & 793 & [18] \\
\hline Nio & H $3-4$ & $08 / 08 / 1897$ & 0.467 & 795 & {$[16,19]$} \\
\hline Kesen & $\mathrm{H} 4$ & $12 / 06 / 1850$ & 135 & 858 & {$[2,19]$} \\
\hline Numakai & $\mathrm{H} 4$ & $05 / 09 / 1925$ & 0.363 & 860 & {$[7,8]$} \\
\hline Tomiya & $\mathrm{H} 4-5$ & $22 / 08 / 1984$ & 0.0275 & 690 & [17] \\
\hline Sone & H5 & $14 / 05 / 1867$ & 17.1 & 1000 & {$[3,17,19]$} \\
\hline $\begin{array}{l}\text { Takeno- } \\
\text { uchi }\end{array}$ & H 5 & $18 / 02 / 1880$ & 0.72 & 860 & {$[6,17,19]$} \\
\hline Kamiomi & H5 & about 1915 & 0.448 & 1000 & \\
\hline Okabe & H 5 & 26/11/1958 & & 938 & {$[5,17,19]$} \\
\hline Ogi & H 6 & $08 / 07 / 1741$ & 14.4 & 1000 & {$[14]$} \\
\hline $\begin{array}{l}\text { Higashi- } \\
\text { Koen }\end{array}$ & H6 & $11 / 08 / 1897$ & 0.75 & 880 & {$[16]$} \\
\hline
\end{tabular}

Table 2. Nuclear data of $\mathrm{Cl}$ and $\mathrm{Br}$ used in this work.

\begin{tabular}{|c|c|c|c|c|c|}
\hline \multicolumn{3}{|c|}{ Stable nuclides } & \multicolumn{3}{|c|}{ Produced nuclides ${ }^{c}$} \\
\hline & $\begin{array}{l}\text { Isotopic } \\
\text { abun- } \\
\text { dance } \\
(\%)^{\mathrm{a}}\end{array}$ & $\begin{array}{l}(\mathrm{n}, \gamma) \\
\text { cross } \\
\text { section } \\
\text { (barns) }^{b}\end{array}$ & & half-life & $\begin{array}{l}\text { measured } \\
\gamma \text {-ray } \\
\text { energy } \\
(\mathrm{kev})\end{array}$ \\
\hline${ }^{37} \mathrm{Cl}$ & 24.23 & 0.428 & ${ }^{38} \mathrm{Cl}$ & $37.245 \mathrm{~min}$ & $\begin{array}{l}1643 \\
2168\end{array}$ \\
\hline${ }^{81} \mathrm{Br}$ & 49.31 & 2.7 & ${ }^{82} \mathrm{Br}$ & $1.4709 \mathrm{~d}$ & $\begin{array}{r}554.3 \\
619.1 \\
698.3 \\
776.5 \\
1044.0 \\
1317.5\end{array}$ \\
\hline
\end{tabular}

${ }^{a}$ [23], ${ }^{b}[24],{ }^{c}[25]$.

in ${ }^{80} \mathrm{Kr}$ and ${ }^{82} \mathrm{Kr}$, a second measurement was carried out with a large-size sample. The powdered samples of $0.736 \mathrm{~g}$ were heated at successively higher temperatures of $600,850,1100,1350,1600$ and $1750^{\circ} \mathrm{C}$. Each temperature was kept constant for 25 minutes.

Typical blanks were ${ }^{4} \mathrm{He}: 5 \times 10^{-10},{ }^{20} \mathrm{Ne}: 3 \times$ $10^{-11},{ }^{36} \mathrm{Ar}: 4 \times 10^{-11},{ }^{84} \mathrm{Kr}: 1 \times 10^{-12}$ and ${ }^{132} \mathrm{Xe}$ : $3 \times 10^{-13} \mathrm{~cm}^{3}$ STP. Corrections for doubly-charged ${ }^{40} \mathrm{Ar}$ and $\mathrm{CO}_{2}$ ions were smaller than $1 \%$ in most cases. The mass spectrometer was tuned at the mass resolution of 700 to separate $\mathrm{H}_{3}$ and $\mathrm{HD}$ ions from
${ }^{3} \mathrm{He}$, and hydrocarbon ions from $\mathrm{Ar}, \mathrm{Kr}$ and $\mathrm{Xe}$ isotopes. Details of the analytical instrument and techniques have been given elsewhere [21, 22].

\subsection{Thermal Neutron Activation Analysis of $\mathrm{Cl}$ and $\mathrm{Br}$}

0.04-0.08 g sized aliquots of powdered chondrites were sealed into polyethylene bags or quartz tubes depending on neutron irradiation conditions. Thermal neutron irradiation was carried out at the reactors JRR-2 or JRR-4 of the Japan Atomic Energy Research Institute at Tokai. Nuclear data of $\mathrm{Cl}$ and $\mathrm{Br}$ used in this work are presented in Table 2. Determination of $\mathrm{Cl}$ and $\mathrm{Br}$ in Fukutomi was repeated 4 times each. Based on the half-lives of the produced nuclides ${ }^{38} \mathrm{Cl}$ and ${ }^{82} \mathrm{Br}$, the experimental conditions were chosen as follows:

i) Non-destructive analysis of $\mathrm{Cl}$.

Total thermal neutron flux: $3.2,6.5$ and $9.6 \times$ $10^{15} \mathrm{n} / \mathrm{cm}^{2}$.

Irradiation periods: 1 or 2 minutes.

ii) Non-destructive analysis of $\mathrm{Br}$.

Total thermal neutron flux: $6.5 \times 10^{16}, 1.1 \times 10^{18}$ and $6.5 \times 10^{15} \mathrm{n} / \mathrm{cm}^{2}$.

Irradiation periods: 20 minutes, 5.5 hours and 2 minutes, respectively.

iii) Radiochemical analysis of $\mathrm{Cl}$ and $\mathrm{Br}$.

Total thermal neutron flux: $1.8 \times 10^{17} \mathrm{n} / \mathrm{cm}^{2}$.

Irradiation periods: 40 minutes.

For non-destructive analyses, the irradiated samples were cooled for $60-70$ minutes and about 2 days for ${ }^{38} \mathrm{Cl}$ and ${ }^{82} \mathrm{Br}$, respectively, then $\gamma$-rays were measured by a $\mathrm{Ge}(\mathrm{Li}) \gamma$-ray spectrometer.

The irradiated sample for radio-chemical analysis was fused with $\mathrm{NaOH}$ and $\mathrm{Na}_{2} \mathrm{O}_{2}$ with approximately $10 \mathrm{mg}$ each of $\mathrm{Cl}^{-}$and $\mathrm{Br}^{-}$carriers in a nickel crucible. After having cooled to room temperature, the fused cake was dissolved in $\mathrm{H}_{2} \mathrm{O}$. The solution was filtered and slightly acidified with $\mathrm{HNO}_{3}$. The mixture of $\mathrm{AgCl}$ and $\mathrm{AgBr}$ was precipitated with $\mathrm{AgNO}_{3}$, then filtered with a 1 inch-diameter-membrane-filter for $\gamma$-ray counting.

\section{Results}

\subsection{Noble Gases}

Results on the concentrations and isotopic ratios of noble gases are listed in Tables 3 and 4 for the melting 
Table 3. Concentrations and isotopic ratios of noble gases released by melting at $1750^{\circ} \mathrm{C}$.

\begin{tabular}{|c|c|c|c|c|c|c|c|c|c|c|}
\hline Meteorite & ${ }^{4} \mathrm{He}^{\mathrm{a}}$ & ${ }^{3} \mathrm{He} /{ }^{4} \mathrm{He}$ & ${ }^{21} \mathrm{Ne}^{\mathrm{a}}$ & ${ }^{22} \mathrm{Ne} /{ }^{21} \mathrm{Ne}$ & ${ }^{20} \mathrm{Ne} /{ }^{22} \mathrm{Ne}$ & ${ }^{36} \mathrm{Ar}^{\mathrm{a}}$ & ${ }^{38} \mathrm{Ar} /{ }^{36} \mathrm{Ar}$ & ${ }^{40} \mathrm{Ar} /{ }^{36} \mathrm{Ar}$ & ${ }^{84} \mathrm{Kr}^{\mathrm{a}}$ & ${ }^{132} \mathrm{Xe}^{\mathrm{a}}$ \\
\hline Fukutomi (L4) & 11600 & $0.0123(08)$ & 38.2 & $1.316(07)$ & $2.427(12)$ & 273 & $0.212(03)$ & $149.2(1.5)$ & 0.823 & 0.758 \\
\hline Tane (L 5) & 18300 & $0.0427(28)$ & 151 & $1.124(06)$ & $0.832(05)$ & 18.4 & $0.997(22)$ & $3317(53)$ & 0.0736 & 0.0764 \\
\hline Nogata $^{\text {b }}($ L 6) & 29900 & $0.0309(08)$ & 158 & $1.168(22)$ & $0.825(14)$ & 25.9 & $0.868(04)$ & $3320(60)$ & 0.27 & 0.11 \\
\hline Nagai (L6) & 3910 & $0.0255(04)$ & 27.6 & $1.092(07)$ & $0.829(06)$ & 5.90 & $0.577(72)$ & $4960(620)$ & 0.0801 & 0.110 \\
\hline Duwun (L6) & 3090 & $0.0781(20)$ & 58.6 & $1.085(07)$ & $0.832(07)$ & 11.2 & $0.677(07)$ & $379(05)$ & 0.056 & 0.032 \\
\hline Shibayama (L6) & 2270 & $0.0661(23)$ & 44.7 & $1.144(16)$ & $0.860(16)$ & 11.6 & $0.622(11)$ & $1015(08)$ & 0.345 & 0.215 \\
\hline Aomori (L6) & 7920 & $0.1059(14)$ & 143 & $1.133(05)$ & $0.832(04)$ & 24.4 & $0.870(10)$ & $803.5(1.1)$ & 0.170 & 0.187 \\
\hline Kokubunji (L6) & 5730 & $0.0555(19)$ & 54.4 & $1.157(09)$ & $0.842(11)$ & 10.7 & $0.806(15)$ & $4773(32)$ & 0.117 & 0.257 \\
\hline $\mathrm{NiO}^{\mathrm{c}}$ (H 3-4) & 137000 & $0.00352(05)$ & 124 & $1.460(04)$ & $3.253(22)$ & 66.7 & $0.484(10)$ & $1124(16)$ & 0.237 & 0.359 \\
\hline Kesen (H 4) & 13800 & $0.0104(07)$ & 32.0 & $1.087(06)$ & $0.839(06)$ & 17.7 & $0.409(15)$ & $2925(24)$ & 0.142 & 0.192 \\
\hline Numakai (H4) & 17900 & $0.00532(17)$ & 16.4 & $1.111(10)$ & $0.857(99)$ & 18.8 & $0.288(05)$ & $3050(110)$ & 0.189 & 0.311 \\
\hline Tomiya (H 4-5) & 13000 & $0.00855(12)$ & 22.5 & $1.144(10)$ & $0.825(13)$ & 12.7 & $0.453(09)$ & $4940(220)$ & 0.144 & 0.330 \\
\hline Sone (H 5) & 11100 & $0.0180(02)$ & 52.4 & $1.087(02)$ & $0.835(04)$ & 8.27 & $0.685(18)$ & $4780(130)$ & 0.0631 & 0.118 \\
\hline Takenouchi (H 5) & 3380 & $0.0212(06)$ & 43.6 & $1.068(09)$ & $0.994(13)$ & 21.9 & $0.404(10)$ & $1678(56)$ & 0.177 & 0.124 \\
\hline Kamiomi (H 5) & 9630 & $0.00992(12)$ & 13.9 & $1.222(10)$ & $0.785(07)$ & 8.37 & $0.414(21)$ & $3930(420)$ & 0.0865 & 0.114 \\
\hline Okabe (H 5) & 13500 & $0.00879(57)$ & 21.9 & $1.109(10)$ & $0.840(05)$ & 10.2 & $0.465(27)$ & $5440(320)$ & 0.0936 & 0.162 \\
\hline Ogi (H 6) & 19100 & $0.0279(08)$ & 76.0 & $1.179(07)$ & $0.824(06)$ & 16.8 & $0.928(06)$ & $3970(80)$ & 0.124 & 0.044 \\
\hline Higashi-Koen $^{c}(\mathrm{H} 6)$ & 17000 & $0.00703(19)$ & 26.9 & $1.071(22)$ & $0.854(17)$ & 12.8 & $0.392(13)$ & $4590(270)$ & 0.159 & 0.161 \\
\hline
\end{tabular}

Errors of the isotopic ratios in the last two digits are given in parentheses.

a Concentrations are given in unis of $10^{-9} \mathrm{~cm}^{3} \mathrm{STP} / \mathrm{g}$. b: [16], ${ }^{\mathrm{c}}$ : [17].

Table 4. Isotopic ratios of Xe in Japanese chondrites.

\begin{tabular}{|c|c|c|c|c|c|c|c|c|c|}
\hline & $\begin{array}{l}{ }^{132} \mathrm{Xe} \\
\left(10^{-9} \mathrm{~cm}^{3} / \mathrm{g}\right)\end{array}$ & ${ }^{124} \mathrm{Xe}$ & ${ }^{126} \mathrm{Xe}$ & ${ }^{128} \mathrm{Xe}$ & ${ }^{129} \mathrm{Xe}{ }^{132} \mathrm{X}$ & ${ }_{100}^{130} \mathrm{Xe}$ & ${ }^{131} \mathrm{Xe}$ & ${ }^{134} \mathrm{Xe}$ & ${ }^{136} \mathrm{Xe}$ \\
\hline Fukutomi & 0.758 & $0.443(27)$ & $0.435(21)$ & $8.38(17)$ & $152.5(1.7)$ & $16.3(0.3)$ & $81.5(0.8)$ & $38.0(0.6)$ & $32.0(0.5)$ \\
\hline Aomori & 0.187 & $0.62(05)$ & $0.64(04)$ & $8.41(25)$ & $116.1(1.0)$ & $16.3(0.4)$ & $83.0(1.7)$ & $38.5(0.5)$ & $32.2(0.7)$ \\
\hline Numakai & 0.311 & - & - & $9.04(60)$ & $125.9(2.4)$ & $16.41(58)$ & $81.7(1.3)$ & $37.4(1.0)$ & $31.3(0.9)$ \\
\hline Tomiya & 0.330 & $0.47(04)$ & $0.43(05)$ & $8.03(23)$ & $143.1(0.9)$ & $16.0(0.2)$ & $82.4(0.4)$ & $38.4(0.3)$ & $32.1(0.2)$ \\
\hline Takenouchi & 0.124 & $0.50(14)$ & $0.41(03)$ & $8.36(66)$ & $126.7(3.4)$ & $16.4(0.5)$ & $81.2(1.4)$ & $37.6(1.1)$ & $31.6(1.0)$ \\
\hline Higashi-Koen & 0.161 & - & - & $8.25(48)$ & $138.5(3.5)$ & $15.8(1.2)$ & $82.4(2.6)$ & $38.9(0.8)$ & $32.9(1.7)$ \\
\hline
\end{tabular}

Errors of the isotopic ratios in the last two digits are given in parentheses. 
Table 5. Concentrations and isotopic ratios of noble gases released by step-heating of Fukutomi.

\begin{tabular}{|c|c|c|c|c|c|c|c|}
\hline Isotope & $600^{\circ} \mathrm{C}$ & $850^{\circ} \mathrm{C}$ & $1100^{\circ} \mathrm{C}$ & $1350^{\circ} \mathrm{C}$ & $1600^{\circ} \mathrm{C}$ & $1750^{\circ} \mathrm{C}$ & Total \\
\hline $\begin{array}{l}{ }^{4} \mathrm{He}\left(10^{-6} \mathrm{~cm}^{3} / \mathrm{g}\right) \\
{ }^{3} \mathrm{He} /{ }^{4} \mathrm{He}\end{array}$ & $\begin{array}{l}3.61 \\
0.02143(67)\end{array}$ & $\begin{array}{l}4.86 \\
0.00919(29)\end{array}$ & $\begin{array}{l}1.67 \\
0.00539(17)\end{array}$ & $\begin{array}{l}0.358 \\
0.00764(28)\end{array}$ & $\begin{array}{l}0.0536 \\
0.02680(91)\end{array}$ & $\begin{array}{l}0.00131 \\
0.0041(07)\end{array}$ & $\begin{array}{l}10.533 \\
0.01282(40)\end{array}$ \\
\hline $\begin{array}{l}{ }^{22} \mathrm{Ne}\left(10^{-9} \mathrm{~cm}^{3} / \mathrm{g}\right) \\
{ }^{20} \mathrm{Ne} /{ }^{22} \mathrm{Ne} \\
{ }^{21} \mathrm{Ne} /{ }^{22} \mathrm{Ne}\end{array}$ & $\begin{array}{l}3.42 \\
1.551(14) \\
0.8241(82)\end{array}$ & $\begin{array}{l}6.98 \\
1.383(10) \\
0.8319(78)\end{array}$ & $\begin{array}{l}10.5 \\
2.295(14) \\
0.7682(45)\end{array}$ & $\begin{array}{l}13.2 \\
3.144(18) \\
0.7078(34)\end{array}$ & $\begin{array}{l}7.21 \\
2.039(11) \\
0.8060(50)\end{array}$ & $\begin{array}{l}0.273 \\
1.405(39) \\
0.858(33)\end{array}$ & $\begin{array}{l}41.58 \\
2.300(14) \\
0.7716(53)\end{array}$ \\
\hline $\begin{array}{l}{ }^{36} \mathrm{Ar}\left(10^{-9} \mathrm{~cm}^{3} / \mathrm{g}\right) \\
{ }^{38} \mathrm{Ar} /{ }^{36} \mathrm{Ar} \\
{ }^{40} \mathrm{Ar} /{ }^{36} \mathrm{Ar}\end{array}$ & $\begin{array}{c}6.29 \\
0.220(03) \\
3000(350)\end{array}$ & $\begin{array}{c}9.79 \\
0.2058(19) \\
1215(27)\end{array}$ & $\begin{array}{l}46.7 \\
0.2017(21) \\
116.3(2.1)\end{array}$ & $\begin{array}{l}143 \\
0.2063(19) \\
10.00(13)\end{array}$ & $\begin{array}{l}36.6 \\
0.2135(18) \\
6.271(54)\end{array}$ & $\begin{array}{l}1.09 \\
0.2220(23) \\
8.86(60)\end{array}$ & $\begin{array}{l}243.47 \\
0.2069(20) \\
155(11)\end{array}$ \\
\hline $\begin{array}{l}{ }^{84} \mathrm{Kr}\left(10^{-12} \mathrm{~cm}^{3} / \mathrm{g}\right) \\
{ }^{78} \mathrm{Kr} /{ }^{84} \mathrm{Kr} \\
{ }^{80} \mathrm{Kr} /{ }^{84} \mathrm{Kr} \\
{ }^{82} \mathrm{Kr} /{ }^{84} \mathrm{Kr} \\
{ }^{83} \mathrm{Kr} /{ }^{84} \mathrm{Kr} \\
{ }^{86} \mathrm{Kr} /{ }^{84} \mathrm{Kr}\end{array}$ & $\begin{array}{l}60.0 \\
0.81(22) \\
15.6(1.3) \\
24.2(0.2) \\
20.6(0.2) \\
30.2(0.8)\end{array}$ & $\begin{array}{l}44.5 \\
0.81(18) \\
25.5(1.1) \\
28.43(52) \\
20.63(46) \\
30.63(34)\end{array}$ & $\begin{array}{l}96.9 \\
0.66(10) \\
11.39(21) \\
22.68(48) \\
20.63(45) \\
30.52(71)\end{array}$ & $\begin{array}{l}413 \\
0.688(48) \\
5.860(47) \\
20.87(09) \\
20.19(19) \\
30.86(22)\end{array}$ & $\begin{array}{c}133 \\
0.705(33) \\
4.91(35) \\
20.66(60) \\
20.15(29) \\
30.54(53)\end{array}$ & $\begin{array}{l}4.83 \\
- \\
4.5(2.0) \\
21.4(1.6) \\
18.9(1.5) \\
29.8(2.0)\end{array}$ & $\begin{array}{c}752.23 \\
0.700(73) \\
8.33(30) \\
21.78(27) \\
20.29(27) \\
30.68(40)\end{array}$ \\
\hline $\begin{array}{l}132 \mathrm{Xe}\left(10^{-12} \mathrm{~cm}^{3} / \mathrm{g}\right) \\
{ }^{124} \mathrm{Xe} / 132 \mathrm{Xe} \\
{ }^{126} \mathrm{Xe} /{ }^{132} \mathrm{Xe} \\
{ }^{128} \mathrm{Xe} /{ }^{132} \mathrm{Xe} \\
{ }^{129} \mathrm{Xe} /{ }^{132} \mathrm{Xe} \\
{ }^{130} \mathrm{Xe} /{ }^{132} \mathrm{Xe} \\
{ }^{131} \mathrm{Xe} /{ }^{132} \mathrm{Xe} \\
{ }^{134} \mathrm{Xe} /{ }^{132} \mathrm{Xe} \\
{ }^{136} \mathrm{Xe} /{ }^{132} \mathrm{Xe}\end{array}$ & $\begin{array}{c}143 \\
0.474(56) \\
0.404(92) \\
8.29(45) \\
116.7(1.4) \\
15.90(28) \\
81.73(87) \\
38.01(18) \\
31.51(57)\end{array}$ & $\begin{array}{l}36.4 \\
0.54(16) \\
0.50(12) \\
8.91(55) \\
117.1(2.4) \\
16.15(65) \\
82.4(1.2) \\
37.68(40) \\
31.3(1.1)\end{array}$ & $\begin{array}{c}85.6 \\
0.448(63) \\
0.458(64) \\
8.70(26) \\
224.1(2.6) \\
15.99(27) \\
81.9(1.3) \\
38.13(71) \\
31.47(49)\end{array}$ & $\begin{array}{l}414 \\
0.472(23) \\
0.429(26) \\
8.47(12) \\
141.0(1.1) \\
16.44(14) \\
82.62(75) \\
37.86(35) \\
31.27(36)\end{array}$ & $\begin{array}{l}138 \\
0.502(36) \\
0.467(62) \\
8.51(24) \\
133.9(2.2) \\
16.29(22) \\
82.66(77) \\
37.51(36) \\
31.08(32)\end{array}$ & $\begin{array}{c}6.23 \\
- \\
- \\
8.48(45) \\
169.6(6.1) \\
15.78(84) \\
83.7(4.1) \\
37.8(1.7) \\
31.5(1.0)\end{array}$ & $\begin{array}{c}823.33 \\
0.478(41) \\
0.437(52) \\
8.49(23) \\
145.8(2.3) \\
16.26(22) \\
82.40(87) \\
37.85(37) \\
31.30(44)\end{array}$ \\
\hline
\end{tabular}

Errors of the isotopic ratios in the last two digits are given in parentheses.

runs of all samples and in Table 5 for the temperature run of Fukutomi. Noble gas data for Nogata, Nio and Higashi-Koen, which have been reported elsewhere $[15,16]$, are included for comparison with other Japanese chondrites. Both concentrations and isotopic ratios were corrected for mass discrimination and blank. Errors quoted are based on statistical errors (95\% confidence of $t$-distribution) of ratio measurements and uncertainties in the mass discrimination and blank corrections. The precision for the gas concentrations is estimate to be about $10 \%$ for $\mathrm{He}$, $\mathrm{Ne}$ and $\mathrm{Ar}$, and $15 \%$ for $\mathrm{Kr}$ and $\mathrm{Xe}$, based on temporal changes in spectrometer sensitivities.

Helium is a mixture of spallogenic and radiogenic gases for all samples except Nio(H3-4). The spallogenic gas dominates in Ne except for Nio and Fukutomi (L4), which contain trapped Ne. Argon is composed of the trapped, spallogenic and radiogenic components. To distinguish these components, the following isotopic ratios are assumed: For the trapped gases, ${ }^{20} \mathrm{Ne} /{ }^{22} \mathrm{Ne}=12.53,{ }^{21} \mathrm{Ne} /{ }^{22} \mathrm{Ne}=0.0335$ [26] and ${ }^{38} \mathrm{Ar} /{ }^{36} \mathrm{Ar}=0.188$ [27]; for the spallogenic gases ${ }^{3} \mathrm{He} /{ }^{4} \mathrm{He}=0.2,{ }^{20} \mathrm{Ne} /{ }^{22} \mathrm{Ne}=0.85$ and ${ }^{38} \mathrm{Ar} /{ }^{36} \mathrm{Ar}=1.5$ [28].
The ${ }^{4} \mathrm{He}$ concentrations for the L 6 chondrites except Nogata, Tane and Fukutomi in Table 3 are significantly low, suggestive of gas loss. Nogata (L 6) retains radiogenic $\mathrm{He}$ quantitatively. Among the H-chondrites investigated, Nio contains very much ${ }^{4} \mathrm{He}$ and a considerable amount of trapped $\mathrm{Ne}$. The ${ }^{4} \mathrm{He}$ content, the $\mathrm{Ne}$ isotopic ratios, and the trapped ${ }^{20} \mathrm{Ne} /$ ${ }^{36} \mathrm{Ar}$ ratio indicate that this chondrite is a solar-gasrich meteorite [29]. Takenouchi (H5) shows very low ${ }^{4} \mathrm{He}$, indicating severe gas loss.

The Ne isotopic ratios indicate that Fukutomi and Nio contain solar-type $\mathrm{Ne}$ [26]. The ${ }^{20} \mathrm{Ne} /{ }^{22} \mathrm{Ne}$ ratio for Takenouchi is slightly higher than that for the other chondrites. Takenouchi may contain a small amount of trapped $\mathrm{Ne}$, while others do not.

The concentration of trapped Ar in Fukutomi is extraordinarily high compared with ordinary chondrites belonging to type 4 [30]. As mentioned earlier, this chondrite contains solar-type $\mathrm{Ne}$ and is significantly enriched in ${ }^{80} \mathrm{Kr}$ and ${ }^{82} \mathrm{Kr}$. The results for this chondrite will be discussed later in detail.

The trapped gas dominates in $\mathrm{Kr}$ and $\mathrm{Xe}$ for all samples. The Xe isotopic ratios determined for the L-chondrites Fukutomi and Aomori, and the H-chon- 
drites Numakai, Tomiya, Takenouchi and HigashiKoen are given in Table 4. The Xe isotopic ratio indicates that Aomori contains a mixture of AVCC-Xe [31] and minor amounts of spallogenic $\mathrm{Xe}\left({ }^{126} \mathrm{Xe}_{\mathrm{sp}}=\right.$ $4 \times 10^{-13} \mathrm{~cm}^{3} / \mathrm{g}$ ). For other chondrites except Fukutomi, their $\mathrm{Xe}$ isotopic composition agrees with that for AVCC-Xe [31] within experimental errors. The isotopic ratios of $\mathrm{Kr}$ and $\mathrm{Xe}$ in Fukutomi will be discussed later.

\subsection{Neutron Activation Analysis}

Results of neutron activation analyses are tabulated in Table 6. The $\mathrm{Cl}$ and $\mathrm{Br}$ contents in chondrites other than Fukutomi were determined only once for comparison with those in Fukutomi.

Counting errors of $\mathrm{Cl}$ and I data from the non-destructive method always exceed $30 \%$ and even $100 \%$, respectively, because of high background due to radioactivities produced by $(\mathrm{n}, \gamma)$ reactions of main target elements in chondrites. Data with counting errors higher than $100 \%$ are not included in the calculation described in the next section. This is the reason why no I data are given in Table 6. By adoption of longer cooling periods and by using at least 6 different comparable $\gamma$-ray energy peaks of ${ }^{82} \mathrm{Br}$, as is listed in Table 2, Br was measured with errors of less than $10 \%$. If radiochemical determinations were employed, errors were reduced to 3.3 and $1 \%$ for $\mathrm{Cl}$ and $\mathrm{Br}$, respectively, whereby errors arising as the result of chemical procedures are accounted for.

\section{Discussion}

\subsection{Gas-Retention Ages}

Gas-retention ages were calculated from radiogenic ${ }^{4} \mathrm{He}$ and ${ }^{40} \mathrm{Ar}$, assuming all ${ }^{40} \mathrm{Ar}$ determined to be radiogenic, $[\mathrm{U}]=15$ and $12 \mathrm{ppb}$ for $\mathrm{L}$ - and $\mathrm{H}$-chondrites, respectively, and $\mathrm{Th} / \mathrm{U}=3.6$ [32]. The results are given in Table 7. For Fukutomi containing a small amount of solar-type $\mathrm{Ne}$, we assume that $\mathrm{He}$ is a mixture of radiogenic and spallogenic components because it can be interpreted in terms of these components. However, since a contribution of trapped $\mathrm{He}$ can not be perfectly excluded, the $\mathrm{He}$ age may be smaller than that in Table 7. The $\mathrm{K}$ concentrations used are given in Table 1 . That the ${ }^{4} \mathrm{He}$ ages are younger than the ${ }^{40} \mathrm{Ar}$ ages is a normal trend because of low retentivity for $\mathrm{He}$. It is noted that the ${ }^{4} \mathrm{He}$ ages for
Table 6. Results of thermal neutron activation analyses of $\mathrm{Cl}$ and $\mathrm{Br}$.

\begin{tabular}{lll}
\hline Chondrite & $\mathrm{Cl}(\mathrm{ppm})$ & $\mathrm{Br}(\mathrm{ppm})$ \\
\hline Fukutomi & $295(81), 210(75)$ & $4.77(12), 3.06(07), 4.0(0.6)$ \\
& $298(10)^{*}$ & $4.74(05)^{*}$ \\
Duwun & $270(40)$ & $0.70(04)$ \\
Aomori & $47(04)$ & $1.32(09)$ \\
Kesen & $104(11)$ & $\leqq 0.7$ \\
Numakai & $52(03)$ & $1.7(0.3)$ \\
\hline
\end{tabular}

* Results by radiochemical analysis.

Errors in the last two digits are given in parentheses.

Table 7. U/Th-He, K-Ar and cosmic-ray exposure ages.

\begin{tabular}{|c|c|c|c|}
\hline Chondrite & $\begin{array}{l}\text { U/Th-He } \\
\text { age } \\
\text { (Ga) }\end{array}$ & $\begin{array}{l}\text { K-Ar } \\
\text { age } \\
(\mathrm{Ga})\end{array}$ & $\begin{array}{l}\text { Cosmic-ray } \\
\text { age } \\
(\mathrm{Myr})\end{array}$ \\
\hline \multicolumn{4}{|l|}{ L-chondrite } \\
\hline Fukutomi (melt) & 2.6 & $3.49(22)$ & 14 \\
\hline $\begin{array}{l}\text { Fukutomi } \\
\text { (step-heating) }\end{array}$ & 2.4 & $3.38(24)$ & 12 \\
\hline Tane & 3.2 & $4.25(23)$ & 52 \\
\hline Nogata $^{a}$ & 4.5 & $4.75(24)$ & 64 \\
\hline Satuma (Kyushu) & 0.4 & $0.73(09)$ & 37 \\
\hline Nagai & 1.0 & $2.86(27)$ & 8.2 \\
\hline Duwun & 0.5 & $1.05(11)$ & 17 \\
\hline Shibayama & 0.4 & $2.16(18)$ & 17 \\
\hline Aomori & 1.0 & $2.56(19)$ & 51 \\
\hline Kokubunji & 1.2 & $4.19(23)$ & 21 \\
\hline \multicolumn{4}{|l|}{ H-chondrite } \\
\hline $\mathrm{Nio}^{b}$ & - & $4.82(24)$ & 54 \\
\hline Kesen & 3.5 & $4.08(23)$ & 9.9 \\
\hline Numakai & 4.2 & $4.24(24)$ & 5.9 \\
\hline Tomiya & 3.4 & $4.76(25)$ & 9.0 \\
\hline Sone & 2.9 & $3.41(22)$ & 16 \\
\hline Takenouchi & 1.1 & $3.53(22)$ & 12 \\
\hline Kamiomi & 2.7 & $3.14(26)$ & 7.2 \\
\hline Okabe & 3.5 & $4.05(25)$ & 7.6 \\
\hline Ogi & 4.1 & $4.24(23)$ & 34 \\
\hline Higashi-Koen $^{\mathrm{b}}$ & 4.0 & $4.25(27)$ & 7.7 \\
\hline
\end{tabular}

Errors for $\mathrm{K}-\mathrm{Ar}$ ages in the last two digits are given in parentheses.

${ }^{\mathrm{a}}[16],{ }^{\mathrm{b}}[17]$.

the L-chondrite Nogata and for the $\mathrm{H}$-chondrites $\mathrm{Nu}$ makai, Ogi and Higashi-Koen are concordant with the $\mathrm{K}$-Ar ages. Uncertainties in the $\mathrm{K}$ concentrations are rather large because the $\mathrm{K}$ and $\mathrm{Ar}$ measurements were carried out using aliquots of different specimens. We assume $10 \%$ errors for the $\mathrm{K}$ concentrations. Especially, Nio shows heterogeneous structures; it is composed of various kinds of lithic fragments. Therefore, the uncertainty to be cited for this meteorite may be much larger than that given in Table 7 . The very old ages calculated for Nogata, Nio and Tomiya are con- 
sistent with the formation age of meteorites [33] within large uncertainties.

The L-chondrites of type 6, except Nogata, Tane and Kokubunji, give young $\mathrm{K}-\mathrm{Ar}$ ages. This can be assigned to gas loss by impact shock [34]. Evidence for shock has been found in many chondrites studied [1], [9-11], [13-17]. Among others, melt pockets, maskelynitization and plastic deformation observed in Duwun indicate that it experienced strong shock pressure and shock heating [13]. Veining by melting indicates that Nagai experienced local shock melting [9]. Maskelynite found in Satsuma [1] and in Shibayama [11] means melting of plagioclase. Aomori was subject to a shock induced by $0.2-0.25 \mathrm{Mb}$ pressure [17] but does show no evidence for shock heating.

The $\mathrm{H}$-chondrites have old $\mathrm{K}-\mathrm{Ar}$ ages, although some of them show the shock effects [10], [14], [16], [17]. It is noted that Tomiya, that received a moderate shock caused by $0.25 \mathrm{Mb}$ pressure [17], retains radiogenic ${ }^{40} \mathrm{Ar}$ quantitatively, while Aomori, that received a similar shock [17], has lost a considerable part of radiogenic Ar. This suggests that the Ar loss does not result from the moderate shock but that other effects such as shock heating followed by slow cooling are necessary to evolve the radiogenic gas from host minerals.

\subsection{Cosmic-Ray Exposure Ages}

As mentioned, the chondrites except Fukutomi, Nio and Takenouchi contain no trapped Ne. For all these meteorites, the measured ${ }^{21} \mathrm{Ne}$ as well as the ${ }^{22} \mathrm{Ne} /$ ${ }^{21} \mathrm{Ne}$ and ${ }^{3} \mathrm{He} /{ }^{21} \mathrm{Ne}$ ratios represent those of the spallogenic component. Neon in Fukutomi and Nio containing solar-type Ne was corrected for the trapped component. Decomposition into the Ne components is based on the assumption that the $\mathrm{Ne}$ is a two-component mixture between Ne-B [26] and spallogenic $\mathrm{Ne}$, whose isotopic compositions were given earlier. For Takenouchi, the measured ${ }^{21} \mathrm{Ne}$ and ${ }^{22} \mathrm{Ne} /{ }^{21} \mathrm{Ne}$ ratio were adopted for the spallogenic component because the correction for the trapped gas is practically negligible in these isotopes. The ${ }^{3} \mathrm{He} /{ }^{21} \mathrm{Ne}$ and ${ }^{22} \mathrm{Ne} /$ ${ }^{21} \mathrm{Ne}$ ratios fall near the correlation lines given by Eberhardt et al. [35] and Nishiizumi et al. [36] except for Takenouchi. The ${ }^{3} \mathrm{He} /{ }^{21} \mathrm{Ne}$ ratio for Takenouchi is 1.65 , indicating loss of spallogenic ${ }^{3} \mathrm{He}$.

Cosmic-ray exposure ages are given in Table 7. They were calculated using the production rate and shielding correction given by Nishiizumi et al. [36]. Six of the ten $\mathrm{H}$-chondrites have exposure ages between 5.9 and 9.9 Myr. The 6-Myr peak is the major feature in the distribution of exposure ages for $\mathrm{H}$-chondrites [37]. The exposure ages for the L-chondrites range from 8.2 to $64 \mathrm{Myr}$ and do not show clustering.

\subsection{Noble Gases in Fukutomi (L4)}

Figure 1 shows release patterns of noble gas components. No significant difference is found in the release patterns of trapped gases except for enhanced release of trapped $\mathrm{Kr}$ and $\mathrm{Xe}$ at $600^{\circ} \mathrm{C}$. Release peaks for all trapped gases are at $1350^{\circ} \mathrm{C}$. The release patterns of radiogenic gases are different from each other as well as from that of trapped gases. The largest release of radiogenic gas is at $850{ }^{\circ} \mathrm{C}$ for ${ }^{4} \mathrm{He}$ and $600{ }^{\circ} \mathrm{C}$ for ${ }^{40} \mathrm{Ar}$. The suppressed release of radiogenic ${ }^{4} \mathrm{He}$ at $600^{\circ} \mathrm{C}$ suggests preferential $\mathrm{He}$ loss from low retentive sites. An alternative interpretation is a contribution of trapped $\mathrm{He}$ in the $850^{\circ} \mathrm{C}$ and other fractions. There is a significant difference in the release patterns of spallogenic ${ }^{3} \mathrm{He},{ }^{21} \mathrm{Ne}$ and ${ }^{38} \mathrm{Ar}$. This can be explained by differences in the diffusion velocity between these isotopes. Comparison of the release patterns of trapped and spallogenic gases suggests that the trapped gas resides at stable trapping-sites of high activation energy in a host phase and is released by extinction of the trapping sites rather than diffusion through the host phase.

As mentioned earlier, this chondrite contains a small amount of trapped $\mathrm{Ne}$, but the ${ }^{4} \mathrm{He}$ concentration is as low as it can be explained in terms of the spallogenic and radiogenic components. Therefore, it is not a solar-gas-rich-meteorite [29]. However, the concentration of trapped ${ }^{36} \mathrm{Ar}$ is 3.5 times higher than the highest value so far reported for type- 4 ordinary chondrites [30] except solar-gas-rich chondrites [29], whereas the ${ }^{132} \mathrm{Xe}$ concentration is in the range of typical values found in type 4 ordinary chondrites $[38,39]$. The amount of ${ }^{36} \mathrm{Ar}$ produced by neutron capture of ${ }^{35} \mathrm{Cl}$ (Table 8) is too small to explain the ${ }^{36} \mathrm{Ar}$ excess.

The elemental ratio ${ }^{36} \mathrm{Ar} /{ }^{132} \mathrm{Xe}$ of 323 is significantly higher than that for planetary-type gas (e.g., 89 for C2-chondrites [40]), and is rather similar to that for Kenna (255 [41]) and that for clasts in Abee (126-1000 [42]). A component enriched in Ar has been found in E-chondrites [42,43]. The Ar-enriched gas in Fukutomi can be interpreted by mixing of planetary-type and argon-rich gas. (Because $\left({ }^{20} \mathrm{Ne} /{ }^{36} \mathrm{Ar}\right)_{\mathrm{tr}}$ is 0.28 , we 

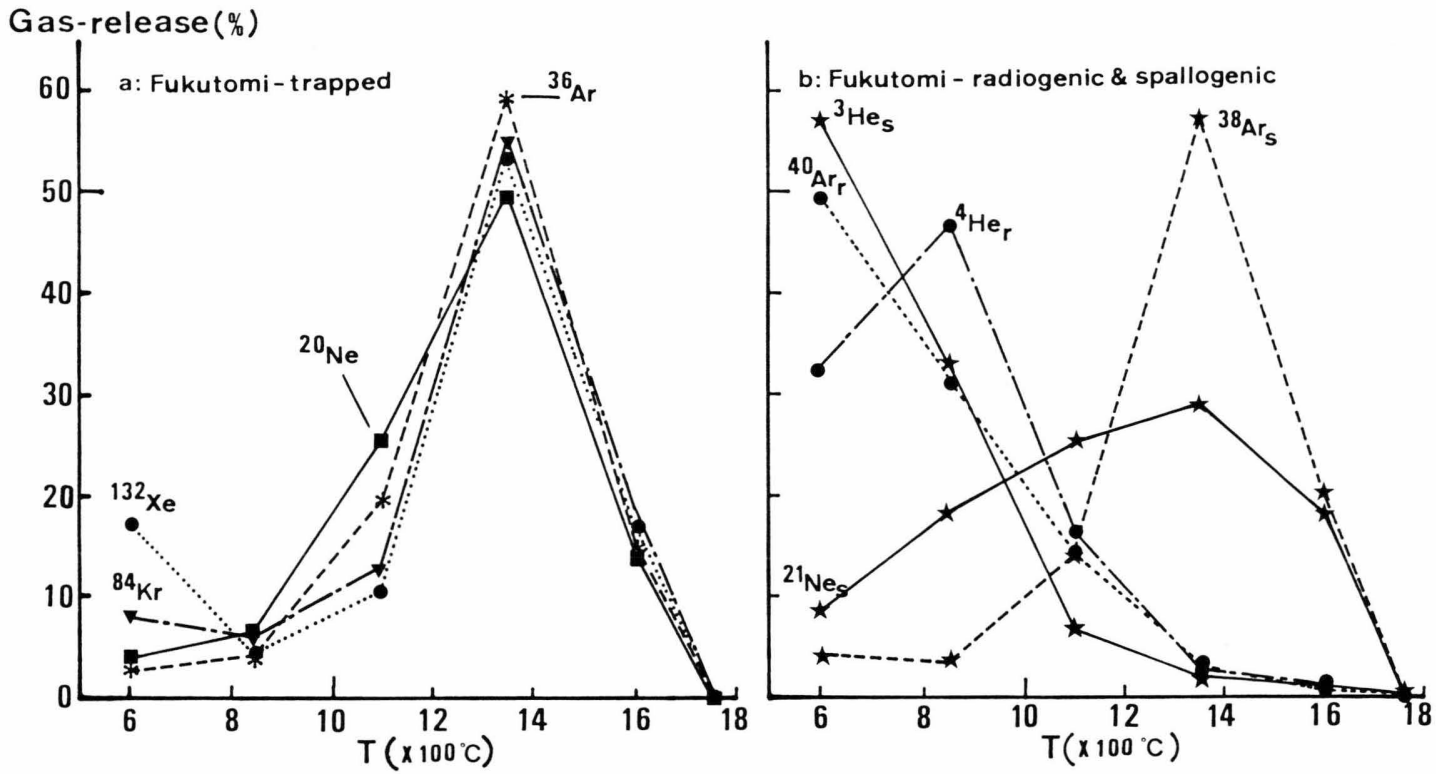

Fig. 1. (a) Release patterns of trapped components. (b) release patterns of radiogenic and spallogenic components from Fukutomi.

use "argon-rich" [42] rather than "sub-solar" [43].) The step-heating experiment failed to isolate the argonrich gas, as shown in Figure 1. This means that the planetary-type and the argon-rich gases were well mixed with each other or were trapped in host phases unseparable by the step-heating experiment.

A correlation line in a three-isotope diagram (Fig. 2) ties Ne-B [26] and spallogenic Ne, indicating that Fukutomi traps solar-type Ne. It is difficult to know the isotopic signature of trapped $\mathrm{Ar}$ because $\mathrm{Ar}$ is a mixture of trapped, spallogenic and radiogenic gases.

The isotopic ratios ${ }^{80} \mathrm{Kr} /{ }^{84} \mathrm{Kr}$ and ${ }^{82} \mathrm{Kr} /{ }^{84} \mathrm{Kr}$ are significantly higher than those of solar-Kr [44] and planetary-Kr [31]. These excesses can be attributed to neutron capture on $\mathrm{Br}$ isotopes in the meteorite. Figure 3 is a correlation diagram between ${ }^{80} \mathrm{Kr} /{ }^{84} \mathrm{Kr}$ and ${ }^{82} \mathrm{Kr} /{ }^{84} \mathrm{Kr}$. All data fall on a straight line to which AVCC-Kr [31] and solar-Kr [44] fit. The slope of the correlation line gives a ratio 2.64 between excessive ${ }^{80} \mathrm{Kr}$ and ${ }^{82} \mathrm{Kr}$. This ratio is significantly lower than that for $\mathrm{Kr}$ produced by thermal neutron capture on $\mathrm{Br}$ isotopes and close to the ratio for $\mathrm{Kr}$ from epithermal neutron capture on $\mathrm{Br}$ isotopes $[45,46]$.

Although neutron capture effects in ${ }^{80} \mathrm{Kr}$ and ${ }^{82} \mathrm{Kr}$ and spallogenic ${ }^{78} \mathrm{Kr}$ make comparison of these isotopes uncertain, the relative abundances of other iso- topes in the $1350^{\circ} \mathrm{C}$ fraction are in agreement with those for AVCC-Kr [31], Kenna [41] and South Oman [43].

Figure 4 shows a comparison of the $\mathrm{Xe}$ isotopic composition between Fukutomi, and Abee [47], Kenna [41], AVCC-Xe [31] and SUCOR-Xe [48]. The $\mathrm{Xe}$ isotopic composition except ${ }^{128} \mathrm{Xe}$ of Fukutomi is indistinguishable from that of Abee and Kenna, while there is definite depletion in the heavy isotopes compared to AVCC-Xe. This is due to fission-like Xe such as $\mathrm{H}-\mathrm{Xe}$ [49] in AVCC-Xe. Fukutomi-Xe is depleted in such fission Xe. The isotopic composition of SUCOR$\mathrm{Xe}$ [48] is different in deficit of the heavy isotopes from Fukutomi-Xe. This indicates a link to the Kenna-type $\mathrm{Xe}$ and/or the E-chondrite $\mathrm{Xe}$ as well.

There is a correlation between ${ }^{128} \mathrm{Xe} /{ }^{132} \mathrm{Xe}$ and ${ }^{129} \mathrm{Xe} /{ }^{132} \mathrm{Xe}$, though the isotopic variation is small. This suggests that Fukutomi contains ${ }^{128} \mathrm{Xe}$ produced by the epithermal neutron capture on ${ }^{127} \mathrm{I}$ [44]. The small ${ }^{128} \mathrm{Xe}$ excess relative to AVCC-Xe (Fig. 4) may be partly attributed to this component.

The isotopic signatures indicate that the noble gases trapped in Fukutomi have similarities to those in E-chondrites and Kenna ureilite in the argon-rich component and the isotopic composition of Xe. The $\mathrm{Kr}$ isotopic ratios do not exclude this possibility. There is a definite difference in Ne, however. Fuku- 


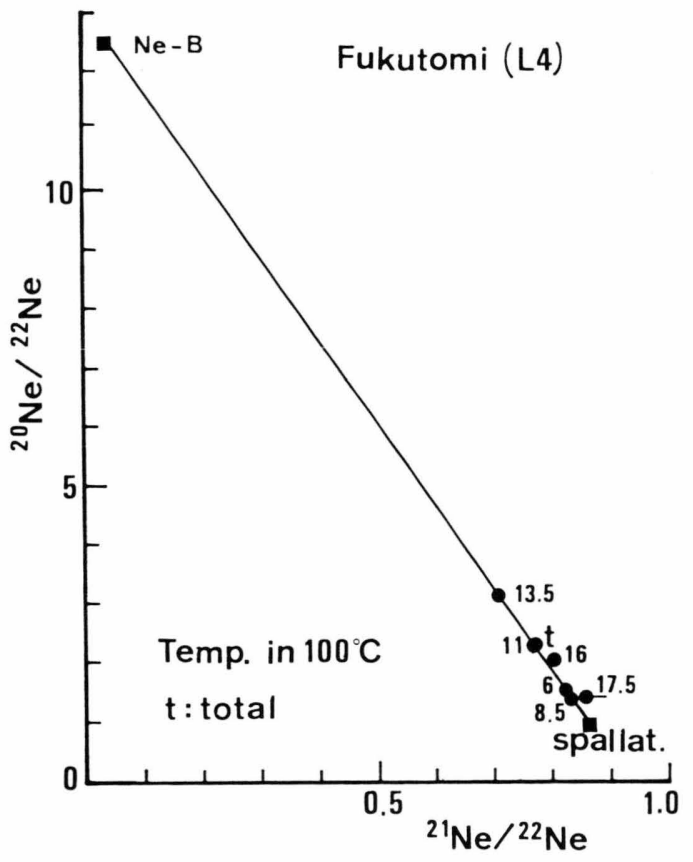

Fig. 2. A three-isotope diagram for Ne released by stepwise heating of Fukutomi. The line obtained by least squares fit for the 650 to $1350^{\circ} \mathrm{C}$ fractions is shown. Numbers in the diagram represent temperatures in units of $100^{\circ} \mathrm{C}$.

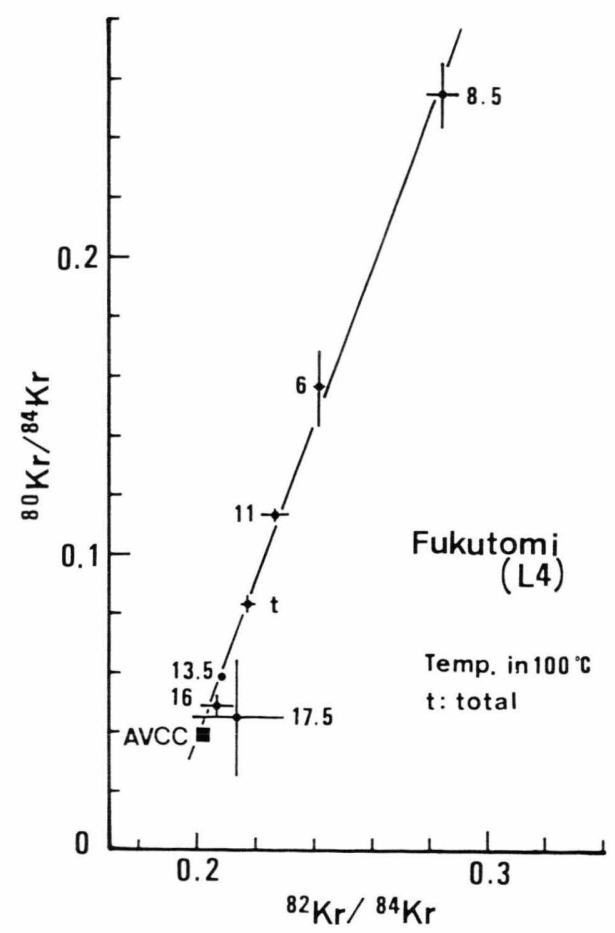

Fig. 3. A correlation diagram between ${ }^{80} \mathrm{Kr} /{ }^{84} \mathrm{Kr}$ and ${ }^{82} \mathrm{Kr}$ ${ }^{84} \mathrm{Kr}$ for Fukutomi.

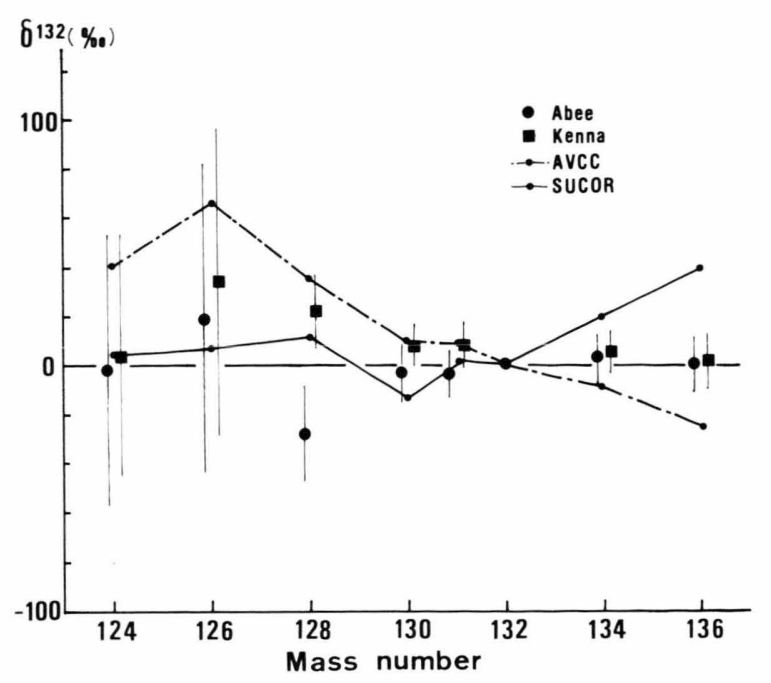

Fig. 4. Comparison of isotopic composition of Fukutomi-Xe with that of Abee-Xe [44], Kenna-Xe [41], AVCC-X [31] and SUCOR-Xe [49]. $\delta$ is defined by

$$
\delta^{132}=1000\left[\left({ }^{\mathrm{m}} \mathrm{Xe} /{ }^{132} \mathrm{Xe}\right)_{\mathrm{F}} /\left({ }^{\mathrm{m}} \mathrm{Xe} /{ }^{132} \mathrm{Xe}\right)_{\mathrm{X}}-1\right],
$$

where $\mathrm{m}$ and $\mathrm{F}$ mean mass number and Fukutomi, respectively, and X means Abee, Kenna, AVCC or SUCOR.

tomi-Ne is $\mathrm{Ne}-\mathrm{B}$ [26], while $\mathrm{Ne}$ in E-chondrites is $\mathrm{Ne}-\mathrm{A} 2$ [50], and $\mathrm{Ne}$ in ureilites is U-Ne [51].

It is interesting to note that Fukutomi contains various kinds of xenolithic parts and fragments. It has been reported that a small part is extraordinarily rich in FeS, about twice compared to the other part [4]. Further. a white lithic fragment consisting of tridymite has been observed [12]. Because tridymite is a rare constituent in ordinary chondrites, and the coexistence of olivine and tridymite is not presumed from the $\mathrm{MgO}-\mathrm{FeO}-\mathrm{SiO}_{2}$ equilibrium system, it is supposed that the tridymite was introduced by a mixing process [12]. This suggests admixing of fragments bearing E-chondritic or ureilitic noble gases by collision. It is unclear whether or not the fragments were E-chondritic or ureilitic because neither E-chondritic nor ureilitic fragments were found in Fukutomi [12]. Anyhow, further work is needed to decompose the planetary gas and the argon-rich gas, to identify the host phases of these trapped gases, and to make the origin of the argon-rich gas clear. Because this is the finding of the argon-rich component in an ordinary chondrite, the detailed study of it will be useful to dicipher the origin of this component in E-chondrites $[42,43]$ as well. 
Table 8. Comparison of observed amounts and theoretical estimates of $\mathrm{Kr}$ and $\mathrm{Ar}$ isotopes produced by epithermal $(30-300 \mathrm{eV})$ neutron capture on $\mathrm{Br}$ and $\mathrm{Cl}$ isotopes.

\begin{tabular}{ccc}
\hline Isotope & Observed & Theoretical \\
\hline${ }^{80} \mathrm{Kr}$ & 33.3 & $\equiv 33.3$ \\
${ }^{82} \mathrm{Kr}$ & 12.2 & 12.4 \\
${ }^{128} \mathrm{Xe}$ & $<1.7$ & 43 \\
${ }^{36} \mathrm{Ar}$ & $<2.4 \times 10^{5}$ & \\
\hline
\end{tabular}

Gas concentration is given in $10^{-12} \mathrm{~cm}^{3} / \mathrm{g}$.

\subsection{Preatmospheric Size of Fukutomi}

Table 8 represents the observed amounts of isotopes produced by neutron capture and the theoretical production estimates in Fukutomi. Information on the neutron absorption cross section and the neutron mean free path in chondrites was taken from Marti et al. [52]. The concentrations of $\mathrm{Cl}$ and $\mathrm{Br}, 296$ and $4.2 \mathrm{ppm}$ respectively, are weighted means of the data in Table 6.

With the method of Eberhardt et al. [53], we obtain $q=0.05 \mathrm{~cm}^{-3} \mathrm{sec}^{-1}$ for the neutron slowing-down density. Using graphical fitting with this slowingdown density and the Fermi age of neutron $(\tau=$ $280 \mathrm{~cm}^{2}$ [46], we find the minimum radius of about $20 \mathrm{~cm}$ on the assumption of a spherical meteoroid.

\section{Summary}

(1) The concentrations of five stable noble gases and the isotopic ratios of $\mathrm{He}, \mathrm{Ne}$ and $\mathrm{Ar}$ are summarized for nineteen Japanese chondrites. Several chondrites were analysed for the Xe isotopic ratios. Step-heating analyses were carried out in Fukutomi. For this meteorite, neutron-capture effects at $\mathrm{Kr}$ and $\mathrm{Xe}$ isotopes and extraordinary Ar-enrichment are found.

(2) $\mathrm{U} / \mathrm{Th}-\mathrm{He}$ ages are younger than $\mathrm{K}-\mathrm{Ar}$ ages for all meteorites studied. Six of the nine L-chondrites give young $\mathrm{K}-\mathrm{Ar}$ ages, suggesting gas loss by impact shock heating. The remaining three $\mathrm{L}$-chondrites and seven of the ten $\mathrm{H}$-chondrites have $\mathrm{K}$-Ar ages older than $4 \mathrm{Ga}$. Effects of shock pressure and shock heating on gas loss were discussed.

[1] B. Mason and H. B. Wiik, Geochim. Cosmochim. Acta 21, 272 (1961).

[2] A. Miyashiro, Jap. J. Geol. Geograph. 33, 73 (1962).

[3] A. Miyashiro, S. Murayama, and H. Haramura, Bull. Natn. Sci. Mus. 6, 352 (1963).

[4] A. Miyashiro, S. Murayama, and H. Haramura, Jap. J. Geol. Geograph. 37, 39 (1966).
(3) Exposure ages for six of the ten $\mathrm{H}$-chondrites show clustering around the 6-Myr peak that is a typical feature for H-chondrites [37], while the exposure ages for L-chondrites ranging from 8.2 to $64 \mathrm{Myr}$ do not show clustering.

(4) Fukutomi (L4) contains solar-type $\mathrm{Ne}$ and trapped ${ }^{36} \mathrm{Ar}$ in excess, 3.5 times enriched compared to the highest value so far reported for type- 4 ordinary chondrites except solar-gas-rich chondrites. The isotopic composition of $\mathrm{Xe}$ is identical with that in Abee [47] and Kenna [41]. The ${ }^{36} \mathrm{Ar} /{ }^{132} \mathrm{Xe}$ and ${ }^{84} \mathrm{Kr} /{ }^{132} \mathrm{Xe}$ ratios fit along a mixing line between a planetary $\left({ }^{36} \mathrm{Ar} /{ }^{132} \mathrm{Xe}=80\right)$ and a subsolar (or argon-rich: 2700 $<{ }^{36} \mathrm{Ar} /{ }^{132} \mathrm{Xe}<3800$ ) component found for separates of E-chondrites [43]. These isotopic signatures of trapped gases, and the chemical and mineralogical features [12] suggest that this meteorite may contain mineral fragments bearing the noble gas component found in E-chondrites and/or ureilites. Further work is needed to isolate the argon-rich gas, to identify the host phase and to understand the origin.

Fukutomi also contains ${ }^{80} \mathrm{Kr},{ }^{82} \mathrm{Kr}$ and ${ }^{128} \mathrm{Xe}$ produced by epithermal neutron capture on ${ }^{79} \mathrm{Br},{ }^{81} \mathrm{Br}$ and ${ }^{127} \mathrm{I}$, respectively. From the $(\mathrm{n}, \gamma)$-produced $\mathrm{Kr}$, the preatmospheric radius is estimated to be at least $20 \mathrm{~cm}$ for a spherical meteoroid.

\section{Acknowledgements}

The authors are indebted to Mr. S. Murayama, National Science Museum, Tokyo, for providing us with the meteorite samples. The authors also express their sincere gratitude to Professor Y. Ito, Mr. T. Takano and other personnel in Tokai Branch, Research Center for Nuclear Science and Technology, the University of Tokyo, and the reactor staff of the Japan Atomic Energy Research Institute, Tokai. Critical comments by Dr. L. Schultz and an anonymous reviewer are greatly appreciated for improving the manuscript. A part of this work was supported by National Universities' Program for the Common Use of JAERI Facilities, the Ministry of Education, Science and Culture.

[5] A. Miyashiro and S. Murayama, Chem. Erde 26, 219 (1967).

[6] A. Miyashiro, S. Murayama, and H. Haramura, Bull. Natn. Sci. Mus. 16, 401 (1973).

[7] M. Shima, Meteoritics 9, 123 (1974).

[8] K. Yagi, Y. Oba, M. Shima, and A. Okada, Ganseki Kobutsu Kosho Gakkaishi 71, 273 (1976). 
[9] S. Murayama, M. Shima, and A. Okada, Bull. Natn. Sci Mus., Ser. E1, 19 (1978).

[10] A. Okada, M. Shima, and S. Murayama, Meteoritics 14, 177 (1979).

[11] M. Shima, S. Murayama, and A. Okada, Meteoritics 14, 317 (1979).

[12] M. Shima, A. Okada, and S. Murayama, Bull. Natn. Sci. Mus., Ser. E 2, 17 (1979).

[13] H. Yabuki and M. Shima, Bull. Natn. Sci. Mus., Ser. E 3, 1 (1980).

[14] H. Yabuki, M. Shima, and S. Murayama, Bull. Natn. Sci. Mus., Ser. E 4, 9 (1981).

[15] M. Shima, S. Murayama, A. Okada, H. Yabuku, and N. Takaoka, Meteoritics 18, 87 (1983).

[16] M. Shima, A. Okada, N. Takaoka, and S. Murayama, Bull. Natn. Sci. Mus., Ser. E 7, 1 (1984).

[17] M. Shima, S. Murayama, F. Wakabayashi, A. Okada, and H. Yabuki, Meteoritics 21, 59 (1986).

[18] M. Shima and S. Murayama, Meteoritics 22, 500 (1987).

[19] S. Yabuki, M. Shima, and N. Takaoka, Meteoritics 16, 406 (1981).

[20] S. Yabuki, M. Shima, and S. Murayama, Meteoritics 20, 789 (1985).

[21] N. Takaoka, Shitsuryo Bunseki (Mass Spectroscopy) 24, 73 (1976)

[22] K. Nagao and N. Takaoka, Mem. Nat. Inst. Polar Res., Spec. Issue 12, 207 (1979).

[23] P. DeBievre, M. Gallet, N. E. Holden, and I. L. Barnes, J. Phys. Chem. Ref. Data 13, 809 (1984).

[24] E. Browne, J. M. Dairiki, and R. E. Doebler, in: Table of Isotopes (Ed. C. M. Lederer and V. S. Shirley), John Wiley \& Sons, New York 1978

[25] E. Browne and R. B. Firestone, in: Table of Radioactive Isotopes (Ed. V. S. Shirley), John Wiley \& Sons, New York 1986.

[26] D. C. Black, Geochim. Cosmochim. Acta 36, 347 (1972).

[27] J. H. Reynolds, U. Frick, J. M. Niel, and D. L. Phinney, Geochim. Cosmochim. Acta 42, 1775 (1978).

[28] M. Ozima and F. A. Podosek, Noble Gas Geochemistry, Cambridge University Press, Cambridge 1983.

[29] J. T. Wasson, Meteorites, Springer, Berlin 1974.

[30] L. Schultz and H. Kruse, Berichte aus der Meteoritenforschung, Max-Planck-Institut für Chemie (Otto Hahn Institut), Mainz 1983.

[31] O. Eugster, P. Eberhardt, and J. Geiss, Earth Planet. Sci. Lett. 3, 249 (1967).
[32] J. W. Morgan, in: Handbook of Elemental Abundances in Meteorites (Ed. B. Mason), p. 529, Gordon and Breach, New York 1971.

[33] T. Kirsten, in: The Origin of the Solar System (Ed. S. F. Dermott), p. 267, John Wiley \& Sons, Chichester 1978

[34] D. Heymann, Icarus 6, 189 (1967).

[35] P. Eberhardt, O. Eugster, J. Geiss, and K. Marti, Z Naturforsch. 21 a, 414 (1966).

[36] K. Nishiizumi, S. Regnier, and K. Marti, Earth Planet. Sci. Lett. 50, 156 (1980).

[37] J. Crabb and L. Schultz, Geochim. Cosmochim. Acta 45, 2151 (1981).

[38] J. Zähringer, Earth Planet. Sci. Lett. 1, 370 (1966).

[39] K. Marti, Earth Planet. Sci. Lett. 2, 193 (1967).

[40] E. Mazor, D. Heymann, and E. Anders, Geochim. Cosmochim. Acta 34, 1781 (1970).

[41] L. Wilkening and K. Marti, Geochim. Cosmochim. Acta 40, 1465 (1976).

[42] J. Wacker and K. Marti, Earth Planet. Sci. Lett. 62, 147 (1983).

[43] J. Crabb and E. Anders, Geochim. Cosmochim. Acta 45 2443 (1981)

[44] P. Eberhardt, J. Geiss, H. Graf, N. Grögler, M. D. Mendia, M. Mörgeli, H. Schwaller, and A. Stettler, Proc. Third, Lunar Sci. Conf. 2, 1821 (1972).

[45] O. Eugster, P. Eberhardt, and J. Geiss, J. Geophys. Res. 74, 3874 (1969)

[46] N. Takaoka and K. Nagao, Z. Naturforsch. 35a, 29 (1980).

[47] B. Srinivasan, R. S. Lewis, and E. Anders, Geochim. Cosmochim. Acta 42, 183 (1978)

[48] F. A. Podosek, J. C. Huneke, D. S. Burnett, and G. J. Wasserburg, Earth Planet. Sci. Lett. 10, 199 (1971)

[49] R. O. Pepin and D. Phinney, Preprint from Space Sci. Center, Univ. Minnesota 1978

[50] L. Alaerts, R. S. Lewis, J. Matsuda, and E. Anders, Geochim. Cosmochim. Acta 44, 189 (1980).

[51] U. Ott, H. P. Lohr, and F. Begemann, Meteoritics 19, $287(1984)$

[52] K. Marti, P. Eberhardt, and J. Geiss, Z. Naturforsch 21 a, 398 (1966)

[53] P. Eberhardt, J. Geiss, and M. Lutz, Earth Science and Meteorites (Comp. J. Geiss and E. D. Goldberg), p. 143, North Holland Publ. Comp., Amsterdam 1963. 